\title{
Determinants of Successful Implementation of Quality Management Systems in Local Government Administration in Sarawak, Malaysia
}

\author{
Ahi Sarok \\ Universiti Malaysia Sarawak
}

\begin{abstract}
Quality management has taken root in the Malaysian public sector in the mid 1990s. Likewise local authorities in Sarawak begin to embark on implementing Total Quality Management (TQM) and MS ISO 9000. In relation to this, a study was carried out on the implementation of TQM and MS ISO 9000 at four local authorities in Sarawak, namely Dewan Bandaraya Kuching Utara (DBKU), Padawan Municipal Council (PMC), Serian District Council (SDC) and Bau District Council (BDC), to determine the factors which influence the success of implementing quality management in the local authorities. The convenience sampling techniques was used to collect data from the respondents. There were 240 employees or internal customers from all the local authorities who were directly involved with the implementation of quality management programmes responded to the self-administered questionnaires. They were asked to relate their experiences on factors which contribute to the successful implementation of quality management programmes at the local authorities. The findings of the study showed that all four local authorities had successfully implemented quality management and practiced the essential elements such as top management support, strategic quality planning, customer focus, teamwork and quality assurance. The benefits derived from the implementation of quality management include providing better service quality to the external customers, better teamwork, increased efficiency, job satisfaction, and maintaining a better organizational culture. The study shows that the successful implementation of quality management in the four local authorities are strongly related to factors such as top management support, strategic quality planning, customer driven, teamwork, training and recognition, good performance appraisal and quality assurance.
\end{abstract}

Keywords: Quality Management Implementation, Local Government Administration, Sarawak Malaysia

\section{Introduction}

The study aims to investigate the perception of internal customers of the factors which influences the successful implementation and adoption of TQM and MS ISO 9000 at 
four local authorities. They are the City Hall of Kuching North or commonly known as Dewan Bandaraya Kuching Utara (DBKU), Padawan Municipal Council (PMC), Serian District Council (SDC) and Bau District Council (BDC). Local governments throughout the world are experiencing dramatic changes. Local authorities are moving away from traditional methods of administration to those which are quality conscious, where emphasis is placed on providing quality services and trying to meet customers' satisfaction. Efficiency of service deliveries, continual improvement of processes, team work approach, and process driven activities seem to be the order of the day. To achieve all these, local authorities have implemented quality management systems such as implementing Total Quality Management (TQM), and the MS ISO 9000 Standards, while others have institutionalised quality assurance mechanisms and business process re-engineering in their organizations.

All the four local authorities have been issued with the MS ISO 9000 certificate.. PMC and DBKU have both implemented TQM and the MS ISO 9000 successfully. BDC and SDC too are also MS ISO 9000 certified. DBKU, in 2001, conducted a citizens' satisfaction survey and used the results to improve the quality system of the office and two years later implemented the IMS. However, smaller local authorities seemed to have both logistic as well as manpower constraints in implementing the system fully. Local authorities that have been certified with the MS ISO 9000 tend to continuously improve their management systems.

Both PMC and BDC have had their application for the license certified under the MS ISO 9002: 1994, and are now in the process of migrating the certification to the MS ISO 9002: 2000. SDC, on the other hand, had its maintenance of public utilities certified under the MS ISO 9002: 1994, and SDC too, is in the process of migrating this quality system to the MS ISO 9002: 2000. On the other hand, DBKU is the sole local authority in this study which has all its business processes and systems certified under the MS ISO 9000, MS 14000 and OHAS, which is collectively known as an integrated management system.

\section{Literature Review}

There many factors that help contribute to the successful implementation of quality management in an organisation. Many writers have claim that top management support is crucial for quality management to succeed, and it must be implemented throughout the organization (Ahmad Sarji, 1996a: Muhammad Rais, 1999: Safiee, 2000; and Evan \& Lindsay, 2002). The implementation phase begins with the top management and the middle management who must all demonstrate that they are serious about quality. There must be clear quality objectives and the quality statement must be set out clearly by the top management.

If the CEO of an organization accepts the responsibility for a commitment to a quality policy, understands what they are committed to, and can articulate and demonstrate their commitment, the impact will be much greater. This action by the chief executive in turn creates responsibilities for interaction between the marketing design, producing, purchasing, distribution, accounting and other service functions. These basic changes in attitude are required at all levels and in every department, starting at the top, to operate TQM. If the top management of the organisation do not recognise 
and accept their responsibility for the initiation and operation of TQM, these essential changes will not happen (Evan \& Lindsay, 2002).

Middle management too, has a particularly important role to play in the successful implementation of quality management. They must not only grasp the principle of TQM, but equally importantly, they must go on to explain them to the people for whom they are responsible and to ensure that their own commitment is communicated. Only then will quality management spread effectively throughout an organisation. Senior management must also ensure that the efforts and achievements of their subordinates are accorded the recognition, attention and reward that they deserve. In essence quality management must involve everyone in the organization.

If quality management is to be successful, the essential factor that must be present is strategic quality planning which must be effective and widespread. Strategic quality planning includes the charting of the organization's grandiose vision, quality objectives and identify the activities that need to be improved. Top management must take the lead in the formulation of the strategic visions, quality objectives and the activities that need to be improved (Edwardson et al, 1994: 51). This strategic vision must be competently communicated throughout the organisation.

However, sometimes managers are good talkers but poor communicators and useful information is not channelled properly across the organisation. The employees must see the results of their activities and the improvements which they have carried out. Quality policies need to be constantly encouraged through active communication in the team. But, Gaster (1995: 29) argues that quality policies tend to be very top down, both in the private and public sector, whether because of the 'guru's maxim' that top management should themselves be committed or because this is how they have always done things. Research conducted by Safiee (2000) finds that strategic quality planning is positively correlated with the successful implementation of TQM. Gaster (1995: 33) further argues that if quality is to improve, changes in work practices and procedures are necessary.

This is done through strategic quality planning. But, strategic quality planning cannot be left to managers alone. According to her, policies to improve quality are often perceived as an attempt by managers to improve the image of their organization and be more responsive to the needs and demands of the current service users. She explains the relationship between the service users and service providers varies accordingly. Users receiving services forced on them by regulation or by the wider needs of the community, and receiving services they depend on for their survival, are in a much weaker position to argue about the nature of those services than users who have some choice, or who are not affected in their day to day live in quite an intimate way.

Logothetis (1992: 3) states that TQM provides an environment where fear is eliminated. If the employees take pride in their work they feel that they are being respected and accepted. They feel part of the same team and they will strive not only for their own interest but also for the interest of the whole organisation. According to him the following fundamental characteristics need to be established in any organisation if it wants to achieve TQM:

Commitment (to never ending quality improvement and innovation), 
Scientific knowledge (of the proper tools and techniques for technical change) and

Involvement (all in one team for social change).

Another important aspect of strategic quality planning is to develop a process of continuous quality improvements and the need to use a selection of quality management tools and techniques. According to Dale (1994: 33) without the effective employment of tools and techniques it will be difficult to solve problems. The tools and techniques should be used to facilitate improvement and be integrated into the routine operations of the business. Organisation needs to develop a route map for the tools and techniques which it intends to use in implementing quality management. The use of tools and techniques helps get the process of improvement started. Employees using them feel involved and that they are making a contribution; quality awareness is enhanced; and behaviour and attitude changes start to happen. In the same notion, Dale (1994: 36) sees that the tools which enhance quality management include statistical analysis, flow charts, improving the design of product or process, controlling the process, capturing and documenting quality system data, solving problems, involving and motivating the people, and promoting awareness.

Alongside top management support, training and recognition, another essential variable for successful TQM implementation efforts is human resource support. Training and recognition is another factor which contributes to successful implementation of TQM. Dale (1994: 12) argues any organisation intending to implement quality management should provide the appropriate level of education and training to its employees to ensure that their general awareness of quality management concepts, skills and attitudes are suited to a continuous improvement philosophy. Training programmes need to provide staff with the vision and skills needed to participate in the new environment. A formal programme of education and training needs to be planned on a timely and regular basis to enable people to cope with increasingly complex problems. Without training it is difficult to solve problems and without education, behaviour and attitude change will not take place.

The training programme must also be focused on helping managers think through what improvements are achievable in their areas of responsibility. Dale (1994) further stresses that the structure of the training programmes needs to incorporate elements such as the updating of basic educational skills in statistics and literacy, and must also promote continuing education and self development. In this way the potential of employees in the organization will be realized.Training and recognition is also an important factor in implementing quality management. Taylor and Wilson (1996: 60) see training and human resource support as the two most important processes variables necessary to implement quality management. Training involves learning how to use quality techniques in an organisational context. They suggest that the role of training varies depending on different quality management programmes. In some cases, Taylor and Wilson (1996: 61) argue that training is used to educate and communicate information, while in some instances training and recognition is used to build skills and teamwork or to create and support planned change in the organisation.

The scale of training also according to them changes according to the size of the organisation and the logistical implications. Some organizations ensure different audiences have different levels of knowledge regarding the change effort (Taylor \& 
Wilson, 1996: 62). Other organisations focus their training on blue and white collar workers with different training programmes for the staff. While other organisations allow their staff design their own training programmes on local requirements.

Human resource policies need to be adapted to support TQM efforts. Recruitment practices need to ensure that suitable customer-focused staff that fit into the new culture are selected. Additionally the human resource department should rally the visible support and commitment of the Chief Executive Officer (CEO) for the change effort.

There must be a commitment to the development of employees, with recognition that they are organizational assets, which appreciate over time. All available means from suggestion schemes to various forms of teamwork must be considered for achieving broad employees interest, participation and contribution in the process of quality improvement; management must be prepared to share some of their powers and responsibilities. This also involves seeking and listening carefully to the views of employees and acting on their suggestions. Part of the approach to TQM is to ensure that everyone has a clear understanding of what is required of them and how their processes relate to the business as a whole. The more people understand the business and what is going on, the greater the role they can play in quality improvement. People have to be encouraged to control, manage and improve the processes which are within their sphere of responsibility.

Gonzalez and Guillen (2002: 152) argue that employees must be able to obtain knowledge about quality concepts through training. The training programmes should incorporate skills required for the handling of quality tools and techniques. The implementation of quality management requires the deployment of systems for diagnosing training needs and suitable resource endowment. In a similar vein, Gonzales and Guillen stress that training efforts must be continued over time in order to adapt to the changing environment which the organization is facing. In quality management, training is applied not only in order to teach the employees about quality management tools, but also to transmit the philosophy of continuous improvement and other quality management principles (Gonzales \& Guillen: 2002: 156).

Training, jointly with teamwork, enables the workforce's involvement in effective problem resolution, and it has been valued by some writers as a key factor in quality management (Peters \& Waterman, 1982; Gonzales \& Guillen, 2002). Aside from training, recognition is an essential element which must be present in the implementation of TQM at R \& DO, Limbang. Saffiee (2000) in his study finds that there is a positive correlation between the successful implementation of TQM and training and recognition. Reward and recognition systems help to motivate employees and boost staff commitment to their jobs in the organisation. Giving rewards and recognitions to the staff makes them feel that they are being appreciated especially after they have shown commitment in undertaking certain tasks, or after they have accomplished certain task previously assigned to them by the top management. In the Malaysian public sector, reward and recognition are often offered to officers who receive the excellent service award. Such recognition is often accorded on the occasion of the organisation's quality day celebration. 
Teamwork is also an important factor that contribute to the successful implementation of quality management in an organisation (Ahmad Sarji, 1966a; Saffiee, 2000; Gonzalez \& Guillen, 2002). Teamwork needs to be practised in a number of forms. Consideration needs to be given to the operating characteristics of the teams employed, how they fit into the organisational structure, and the roles of members, team leaders, sponsors, and facilitators. Teamwork is one of the key features of involvement, without which it is difficult to gain the commitment and participation of people throughout the organisation. There is also a need to recognise positive performance and achievement, and organisations need to celebrate and reward success. According to Gonzalez and Guillen (2002) for successful teamwork to exist, the team members must possess the necessary knowledge, suitable resources and adequate decision-making capability.

The teamwork typology is broad and heterogeneous, and its proper functioning requires empowerment from the top management and leadership. Because of this, work units, administrative teams, or management committees are teams in which there is a relationship between subordinates with clear goals. It must be acknowledged too, that any team cannot function properly without the drive of a leader. A sound performance appraisal system is also a significant prerequisite for the successful implementation of quality management in an organisation. A sound performance appraisal system means quality feedback on the performance of work teams, and individual staff. According to Roberts (1992) a sound performance appraisal system provides effective management of performance and personnel decision making. A sound appraisal system cab also reduce absenteeism, monitor poorly performing employees, and motivate employees.

Performance appraisal establishes the relative value of an individual's contribution to an organization which can be used to provide decisions on layoffs, terminations and promotions. It can also be used for compensation, which determines the appropriate and equitable pay for performances, and bonus incentives based on merit and results. It can also be used for human resource planning, to provide a format for dialogue between superior and subordinates, and to improve understanding of personal goals and concerns. Apart from that, it encourages continued successful performance and targets individuals' weaknesses so that organizations can successfully implement other as quality enhancement strategies. A sound appraisal system is closely related to performance standards. Standards often are established to achieve quantity of output, quality of output, timeliness of results, manner of performance and effectiveness in the use of resources (Roberts, 1992). A sound performance appraisal system is also positively correlated with the successful implementation of TQM in an organization (Safiee, 2000).

If quality management is to be successfully implemented, a quality assurance mechanism need to be put in place (Edvardson, 1994: 82). Measurement and feedback processes need to be carried out continually against a series of key result indicators, both internal and external (Gaster, 1995: 67). Quality assurance is important as it relates to customer perceptions of product or service improvement. The indicators should be developed for external and internal benchmarking, as well as for customer surveys and other means of external input. This enables progress and feedback to be assessed against a roadmap or checkpoints. From these measurements, action plans must be developed to meet the objectives, and corrective actions can be 
taken to rectify the deficiencies in the systems. According to Edvardsson et al, (1994: 84) quality assurance need not be used just externally but can also be used internally. This implies that quality assurance encourages quality improvement to the service. Quality assurance forces organisation to go through processes in detail to decide who is responsible for what, and to specify the demand on the internal service provided by the organisation precisely. Saffiee (2000) further argues that quality assurance has moderately strong correlation with successful implementation of TQM in RDOL.

\section{Methodology}

A convenience sampling technique was employed in collecting data from the employees of the four local authorities. The justification of choosing a convenience sampling is because all internal customers who are officers directly involved in the implementation of the quality management programmes are selected as respondents. The population of the study comprised officers of the four local authorities. In view of the huge number of the population $240 \mathrm{y}$ were selected randomly to answer the self administered questionnaires.

Table 1 shows the total number of respondents or internal customers who responded to the self-administered questionnaires. From the table, 41.7 percent of the respondents were from DBKU, 29.2 percent from MPP, while the remaining 18.8 percent and 10.4 percent were internal customers from BDC and SDC.

Table 1: Distribution of Respondents by Local Authority

\begin{tabular}{|l|c|c|}
\hline \multicolumn{1}{|c|}{ Name of local authority } & $\begin{array}{c}\text { Number of respondents } \\
\text { (n) }\end{array}$ & Percentage \\
\hline DBKU & 100 & 41.7 \\
\hline PMC & 70 & 29.2 \\
\hline SDC & 25 & 10.4 \\
\hline BDC & 45 & 18.8 \\
\hline Total & $\mathbf{2 4 0}$ & $\mathbf{1 0 0 . 0}$ \\
\hline
\end{tabular}

There were 40 items in the questionnaire focusing on the factors contributing to successful implementation of the QMS and respondents were asked to respond based on the five point Lickert scale. Exploratory factor analysis (EFA) and a One Way ANOVA are used to analyse the factors influencing the success of implementing quality management. After all the items had been factorised seven major variables were identified namely, top management support, strategic quality planning, customers driven improvements, training and recognition, teamwork, good performance appraisal systems, and quality assurance. 


\section{Findings and Discussions}

This section discusses the determinants which are perceived to contribute to the successful implementation of quality management in the local authority administration. The discussion is based on empirical data obtained from the questionnaires and is supplemented by information obtained during the face-to-face interviews with informants from all the four local authorities. Seven variables which researchers such as Ahmad Sarji (1996a), Saffiee (2000), Gonzalez and Guillen (2002) and Kafayah Amar and Zuraidah Mohd Zain (2002) have argued are essential elements in the implementation of quality management are included in the discussion. Exploratory factor analysis (EFA) was used to identify the perceived factors which determine the successful implementation of quality management. The results of the EFA are shown in Table 2 below.

Table 2: Results of the Exploratory Factor Analysis on the Factors

\begin{tabular}{|l|c|c|c|c|}
\hline Factors & KMO & $\begin{array}{c}\text { Bartlett Test of } \\
\text { Sphericity }\end{array}$ & $\begin{array}{c}\text { Eigen } \\
\text { Value }\end{array}$ & $\begin{array}{c}\text { Cronbach } \\
\text { Alpha }\end{array}$ \\
\hline Top management support & 0.808 & 273.283 & 27.177 & 0.830 \\
\hline Strategic quality planning & 0.734 & 184.881 & 59.566 & 0.854 \\
\hline Customer driven & 0.866 & 156.651 & 50.193 & 0.796 \\
\hline Training and recognition & 0.786 & 165.343 & 52.493 & 0.786 \\
\hline Teamwork & 0.792 & 175.763 & 49.772 & 0.898 \\
\hline $\begin{array}{l}\text { Good performance appraisal } \\
\text { system }\end{array}$ & 0.763 & 199.722 & 59.737 & 0.806 \\
\hline Quality assurance & 0.784 & 98.087 & 53.772 & 0.713 \\
\hline
\end{tabular}

\section{Top Management Support}

A principle component of extraction on seven items of top management support was used to estimate the number of factors with eigenvalues greater than one. Eigenvalues are a special set of scalars associated with a linear system of equations (i.e., a matrix equation) that are sometimes also known as characteristic roots, characteristic values. The Kiaser-Meyer-Olkin (KMO) measure of sampling adequacy is 0.808 indicating the sampling adequacy of greater than 0.5 for a satisfactory factor analysis to be acceptable. Bartletts test is significant with a Chi-square value of 273.283 (pvalue $=0.000$ ). The result of the factor analysis shown in Table 2 indicates that the total variance explained by the top management support component is 38.82 percent.

A One-way ANOVA was used to further examine whether there exist significant differences between the local authorities with respect to top management support and the results are presented in Table 3, which suggest that there are significant difference $(F=6.101$, with p-value 0.001). The Schefee's Post Hoc Multiple comparison of mean difference indicates that there is a significant difference between DBKU and BDC. 
Table 3: One-way ANOVA on Top Management Support

\begin{tabular}{lccccc}
\hline & $\begin{array}{c}\text { Sum of } \\
\text { Squares }\end{array}$ & $\begin{array}{c}\text { Degree of } \\
\text { Freedom }\end{array}$ & $\begin{array}{c}\text { Mean } \\
\text { Square }\end{array}$ & F & $\begin{array}{c}\text { Significance } \\
\text { P }\end{array}$ \\
\hline $\begin{array}{l}\text { Between } \\
\text { Groups }\end{array}$ & 2.572 & 3 & 0.857 & 6.101 & 0.001 \\
$\begin{array}{l}\text { Within } \\
\text { Groups }\end{array}$ & 33.161 & 236 & 0.141 & & \\
\hline Total & $\mathbf{3 5 . 7 3 3}$ & $\mathbf{2 3 9}$ & & & \\
\hline
\end{tabular}

The findings of this study support the assumption in the literature review that top management is one crucial factor in the successful implementation of quality management in any organisation. The CEO of an organization needs to show commitment and give full support to the implementation of either TQM or the MS ISO 9000 quality management system. Top management commitment is an important prerequisite for change to take place in any aspect of the organisation's policies, philosophy, systems and procedures, structures and the like. Quality management programmes and initiatives must come from the top management because they have the executive power to ensure that such programmes and initiatives must be implemented in the organisation.

Top management commitment and support must take precedence. This can be achieved by taking concrete steps to formulate local authority quality policy statement, establishing a quality management structure, encouraging the participation of staff in decision-making, channelling information on quality, and managing the change processes throughout the organization efficiently. It is also important for local authorities to observe a quality day annually which can be easily planned with approval from the top management.

During the interviews, some informants seemed to concur with the view that without the top management support or commitment, all quality management initiatives which the local authorities want to implement would "go down the drain." In other words, the introduction and implementation of quality management in any organizations is bound to fail if top management does not give their full commitment to such initiatives. Significantly, it is the top management who heads the Steering Committees and selects personnel to be members of the various other committees, and in return these committees report to them.

All the local authorities in the study have utilized their web page as a tool to provide information on the quality management initiatives that they have implemented. Apart from the web pages, the bigger councils, such as DBKU and PMC, have used Council magazines as well as quality corners to disseminate information on quality. The PMC uses its magazine, SUARA MPP to channel information on quality within the organisation, and the same method is employed by the DBKU. Meanwhile the DBKU has gone a step further by setting up a Quality Resource Centre, where all information pertaining to quality management is kept. Members of staff, external customers and the public have access to the Quality Resource Centre at DBKU.

According to the survey, most respondents from all the four local authorities were of the opinion that their organisations have managed the change process well. Seventyfive percent of the respondents agreed that in the process of implementing TQM and 
ISO 9000, the management handled the implementation process satisfactorily. There is a very poor evaluation of the role of top management in local authority quality day celebrations. Either the council did not celebrate the quality day or they might not have celebrated the quality day when the questionnaires were distributed to them. Only DBKU organized quality day in 2002 and 2003.

Information gathered from the face-to-face interviews with some of the informants suggests a number of reasons for this situation. One employee reported that organising a quality day involves resources to finance the activities for the day and smaller local authorities are plagued with financial problems. Another reason is that, the activity is often seen as time consuming and those who are not given any recognition on the day for the effort and work they contribute may not wish to participate in the activities. There is also the possibility that some may boycott the activity. This information is consistent with the finding that the perception is that effective involvement of middle management is important for the success of quality improvement programs in organisation. In this respect, getting middle managers to buy-in and be involved in a positive manner is viewed as key to the success of quality management (Olian \&Rynes, 1991). Similarly, Isikawa (1995) argues that middle managers can contribute greatly towards quality improvement and that top management should pay greater attention to and provide new roles for middle management. These new roles include providing supervision of and leadership in the team.

\section{Strategic Quality Planning}

An EFA was used to determine if strategic quality planning is regarded as a factor essential to the implementation of quality management in local authorities. The result of the Kiaser-Meyer-Olkin (KMO) measure of sampling adequacy is 0.734 indicating that the sampling adequacy of greater than 0.5 for a satisfactory factor analysis is acceptable. Bartlett's test is significant with Chi-square of 184.81 (p-value 0.000). Total variance explained for this component is 49.56 percent (Table 2).

A One-way ANOVA was also conducted to ascertain the significance of difference between the levels of strategic quality planning implemented by the four local authorities and the result is shown in Table 4.

Table 4: One-way ANOVA on Strategic Quality Planning of the Local Authorities

\begin{tabular}{lccccc}
\hline & $\begin{array}{c}\text { Sum of } \\
\text { Squares }\end{array}$ & $\begin{array}{c}\text { Degree of } \\
\text { Freedom }\end{array}$ & $\begin{array}{c}\text { Mean } \\
\text { Square }\end{array}$ & F & $\begin{array}{c}\text { Significance } \\
\text { P }\end{array}$ \\
\hline Between Groups & 0.800 & 3 & 0.267 & 2.426 & 0.000 \\
Within Groups & 25.933 & 236 & 0.110 & & \\
\hline Total & $\mathbf{2 6 . 7 3 3}$ & $\mathbf{2 3 9}$ & & & \\
\hline
\end{tabular}

The One-way ANOVA shows that there is some differences $(\mathrm{F}=2.426$, $\mathrm{p}$-value $>0.05)$ among strategic quality planning currently implemented by the four local authorities. This implies that there is a significant difference in the level of strategic quality planning adopted by the local authorities since the implementation of TQM and MSO 9000 systems in the respective organizations. The finding implies that the respondents overall perceptions of strategic quality planning has a moderately strong influence on 
the successful implementation of quality management in the local authority administration.

This finding is consistent with the conclusion drawn by Safiee (1999) who found that strategic quality planning is an essential factor in the successful implementation of TQM in RDOL, Limbang. According to Edvardsson et al. (1994: 57), it is not sufficient for managers to formulate and initiate the strategies, but they must also guide and participate. A major factor which contributes to the success of strategic quality planning is the interest and commitment of staff. Every member of the organisation needs to be involved if the strategy is to be successful.

Basically there are four important stages in strategic quality planning. In the first stage, organizations wishing to implement TQM and quality management standards such as MS ISO 9000 need to form quality improvement groups which comprise people from different departments. Apart from focusing on quality issues, the group members can learn a great deal and understand the work of their colleagues from the other departments. In addition, they learn more from each other while working in groups.

The second stage, which Edvardsson et al. (1994) see as important, and which all local authorities have reached, is the dissemination of quality messages through different channels. DBKU and MPP fully utilise their in-house bulletins to channel quality messages throughout the organisations.

The third stage is to establish goals for service quality. This is done through the client charters of the local authorities. Every employee of the local authority should deliver services as expected and as pledged in the client charters. In the fourth stage, the task is to ensure that every employee in the organisation knows the consequences of quality errors. Hence, if every employee in the local authority realizes the effect of providing poor services to external customers, the internal customers will be convinced that they too play a part in providing better services to customers.

Strategic quality planning is one of the most important elements in the implementation of TQM in any organization. It is the prerequisite for every organisation to produce quality output in terms of products and services. Strategic quality planning becomes the cornerstone in formulating the organisation's vision and mission. It is also a basis for the organization to continuously improve its service quality.

\section{Customer Driven}

A principle component of extraction through SPSS output on four items of customer driven quality initiative for a sample of 240 respondents was used to estimate the number of factors which forced eigenvalues that exceed one. The Kiaser-Meyer-Olkin (KMO) measure of sampling adequacy is 0.766 indicating that the sampling adequacy of greater than 0.5 for a satisfactory factor analysis is acceptable. Bartlett's test is significant with a Chi-square value of 156.651 (p-value 0.000). The result in Table 4.16 shows that the total variance explained is 50.194 for customer driven component. 
A One-way ANOVA conducted to examine the significant difference between the four local authorities in the level of perceptions of customer driven generates the results are shown in Table 5.

Table 5: One-way ANOVA on Customer Driven of Local Authorities

\begin{tabular}{lccccc}
\hline & $\begin{array}{c}\text { Sum of } \\
\text { Squares }\end{array}$ & $\begin{array}{c}\text { Degree of } \\
\text { Freedom }\end{array}$ & $\begin{array}{c}\text { Mean } \\
\text { Square }\end{array}$ & F & $\begin{array}{c}\text { Significance } \\
\text { P }\end{array}$ \\
\hline Between Groups & 910 & 3 & 0.303 & 5.104 & 0.002 \\
Within Groups & 14.023 & 236 & 0.059 & & \\
\hline Total & $\mathbf{1 4 . 9 3 3}$ & $\mathbf{2 3 9}$ & & & \\
\hline
\end{tabular}

As the results suggest there is a significant difference between the level of perceptions of customer driven between the local authorities ( $\mathrm{F}=5.014$, where p-value 0.002). The Schefee's Post Hoc Multiple comparison of mean difference indicates that the significant difference is between the respondents of DBKU and BDC. This indicates that there could be differences in the customer driven approaches that are being adopted by the two local councils. DBKU has more officers as compared to BDC.

This finding is in agreement with the argument from the literature review that the successful implementation of quality management in any organisation is determined by the customers. Very often, it is commonly stated that a quality service is one that is able to satisfy the needs of the customers (Deming, 1982; Juran, 1988; Ahmad Sarji, 1996a \& 1996b; Johnson, 1996; Idris, et. al., 1996). In implementing quality management in local authorities, it is of paramount importance for the council administration to identify its external customers and the stakeholders. It is only by identifying their needs, conforming to service quality standards, establishing quality output and ensuring the implementation of a quality management system by strictly adhering to work procedures and processes that local authorities can meet the needs and aspirations of external customers.

\section{Training and Recognition}

Five items of training and recognition were used to estimate the number of factors which generate eigenvalues greater than one. The Kiaser-Meyer-Olkin (KMO) measure of sampling adequacy is 0.786 , indicating that a sampling adequacy of greater than 0.5 for a satisfactory factor analysis is acceptable. Bartlett's test is significant with a Chi-square value of 165.343 (p-value 0.000 ). Total variance explained by this component is $52.449 \%$ (Table 6 ).

In addition a One-way ANOVA conducted to ascertain whether there is a significant difference between perception of the level of training and recognition among the employees of the four local authorities is shown in Table 6.

Table 6: One-way ANOVA on Training and Recognition by Local Authorities

\begin{tabular}{lccccc}
\hline & $\begin{array}{c}\text { Sum of } \\
\text { Squares }\end{array}$ & $\begin{array}{c}\text { Degree of } \\
\text { Freedom }\end{array}$ & $\begin{array}{c}\text { Mean } \\
\text { Square }\end{array}$ & F & $\begin{array}{c}\text { Significance } \\
\text { P }\end{array}$ \\
\hline Between Groups & 1.852 & 3 & 0.617 & 3.512 & 0.016 \\
Within Groups & 41.481 & 236 & 0.176 & & \\
\hline Total & $\mathbf{4 3 . 3 3 3}$ & $\mathbf{2 3 9}$ & & & \\
\hline
\end{tabular}


The results suggest that there is a significant difference between the four local authorities with respect to their level of perception on training and recognition. The Schefee's Post Hoc Multiple comparison of mean difference indicates a significant difference between SDC and BDC (p-value 0.019).

The result also indicates a strong relationship between successful implementation of quality management, and training and recognition which confirms the research hypothesis that there is a positive relationship between internal customer perceptions of training and recognition and the successful implementation of quality management.

The implementation of quality management demands a high degree of empowerment by the top management requiring all members in the organisation to have adequate education and training (Gonzalez \& Guillen, 2002: 14). Through training employees are able to obtain knowledge about quality concepts and consequently incorporate this knowledge in handling their daily routines. They are also able to adopt practices such as active listening and cooperation and apply these tools to meet the standards benchmarked by the organisation. Training is also a continuous improvement process that empowers employees. Continuous training efforts enable an organisation to adapt to the ever-changing environment brought about by quality management initiatives (Oakland, 1993, cited in Gonzalez \& Guillen, 2002).

Quality management training enables the local authority to understand TQM and ISO 9000 tools and procedures. Through training, the top management of an organisation is able to transmit the concepts of continuous improvement and other QM principles to employees, and training can and must serve as a mechanism to promote a more conducive working environment where cooperation and teamwork prevail (Ahmad Sarji, 1996b).

Training is the foundation of the successful implementation of quality management in an organization. Adequate training is an enabling factor that enhances efficiency and provides knowledge to staff in relation to the tasks that they perform. Problems related to human resources can be minimized by a more experienced and skilful workforce through training. Adequate training also aims to ensures that there are no defects in the provision of services to customers. However, training goes beyond the transmission of knowledge. It is a practice which is closely linked to the socialization of employees, an indoctrination process which involves the transmission of the organisation's values in the organisation (Ahmad Sarji, 1996a)

According to the Administrative Officer, at MPP, before the implementation of TQM and ISO 9000, section heads and their deputies, senior officers and administrative assistants attended a one-day in-house seminar on awareness of the MS ISO 9000 conducted by INTAN. Approximately two months later, 45 officers from MPP, comprising section heads and their deputies, senior officers and administrative assistants, were involved in a workshop on the implementation of MS ISO 90002 which was also conducted by INTAN. At MPP a sum of approximately RM80,000 was allocated for training, and the amount has increased annually. Similarly, senior staff of SDC and BDC also attended briefings on TQM and MS ISO 9000, which were conducted by the Ministry of Environment and Public Health, Sarawak. 
Rewards and recognition have a significant impact on the successful implementation of TQM. This is a form of recognition given to staff who have given excellent service in the course of carrying out their duties. The findings of the study reveal that 34.2 percent of respondents do not agree that local authorities give recognition for excellent work. This is interesting, and unexpected, because under both the NRS and MRS, employees are expected to be recognised for their excellent service and be appropriately rewarded. However, such awards are only allocated to five percent of the total staff every year. Hence those not nominated for such awards, and who feel that they had performed well, may have disagreed with the statement in the questionnaire.

The CEOs of the local authorities sometimes nominate their employee for both state and the federal awards. State awards are normally granted to recipients who have excellent records in the State Civil Service as well as those officers who have contributed much to community service. In Sarawak, state awards are given during the Governor's, or the Tuan Yang Terutama's, birthday, while federal awards are granted either on the King's birthday or Independence Day.

As a leading local authority in Sarawak, DBKU has an innovative approach to rewarding its employees who give quality suggestions to the management. According to its annual report, staff members who give suggestions are awarded RM1.00 per suggestion. Staff member with the highest number of suggestions per month will have their photographs inserted in the DBKU quality magazine (Warta Kualiti DBKU).

\section{Teamwork}

To determine whether teamwork is perceived to be a crucial factor in determining the successful implementation of quality management, an EFA was conducted on the data set. A principle component of extraction on the four items related to teamwork was used to estimate the number of factors which generates eigenvalues greater than one. The Kiaser-Meyer-Olkin (KMO) measure of sampling adequacy is 0.792 indicating that the sampling adequacy greater than 0.5 for a satisfactory factor analysis is acceptable. The Bartlett's test is significant with a Chi-square value of 175.763 (p-value 0.000) with the total variance explained of $52.449 \%$ for this component (Table 2).

Similarly a One-way ANOVA test was also used to ascertain the significance difference between perception of the level of teamwork among the respondents of the four local authorities. The results are shown in Table 7 below.

Table 7: One-way ANOVA on Teamwork of the Four Local Authorities

\begin{tabular}{lccccc}
\hline & $\begin{array}{c}\text { Sum of } \\
\text { Squares }\end{array}$ & $\begin{array}{c}\text { Degree of } \\
\text { Freedom }\end{array}$ & $\begin{array}{c}\text { Mean } \\
\text { Square }\end{array}$ & F & $\begin{array}{c}\text { Significance } \\
\text { P }\end{array}$ \\
\hline Between Groups & 2.107 & 3 & 0.702 & 3.678 & 0.013 \\
Within Groups & 45.076 & 236 & 0.191 & & \\
\hline Total & $\mathbf{4 7 . 1 8 3}$ & $\mathbf{2 3 9}$ & & & \\
\hline
\end{tabular}

Table 7 shows that there is a significant difference in the perceptions of the level of teamwork among employees of the four local authorities where $(\mathrm{F}=3.678, \mathrm{p}$-value 0.013). The One-way ANOVA Schefee's Post Hoc Multiple comparison of mean 
difference were further conducted to ascertain the significance difference between the group and it is found that there is significant difference in perceptions between the respondents of SDC and BDC. This confirms the research hypothesis which states that there is a positive relationship between internal customer perception of teamwork and the successful implementation of quality management.

These findings support the argument of Peters and Waterman (1982) that teamwork enables the involvement of employees in effective problem-solving. They also argue that teamwork is a key factor in achieving continuous improvement and excellence in an organisation. Kinlaw (1992) claims that generally the effective operation of these teams depends on the members, and that team members need to possess the necessary knowledge, appropriate resources, and adequate decision-making capabilities.

The typology of teamwork in any organisation is broad and often heterogeneous, and depends on the type of team and its members. Gonzalez and Guillen (2002: 157) further stress that the proper functioning of teamwork requires active of managerial power and leadership, where work units, administrative teams, autonomous production groups, and permanent committees are teams in which there is a hierarchical relationship and clear goals.

Work teams are composed of several members who are usually involved in intense communication with each other in a small group. In such a situation the team members are sensitive to the intentions of whoever commands the group. The implementation of TQM and MS ISO 9000 in any organisation needs the total commitment of all the stakeholders. Teamwork is an essential ingredient in implementing quality management in local authorities. With teamwork, all resources can be utilized and channelled fully toward implementing continuous improvement in local authorities. Teamwork is also seen as a motivating factor that contributes to a harmonious working environment in local authorities. The establishment of QCC at the DBKU, MPP, SDC and BDC shows the presence of teamwork.

\section{Good Performance Appraisal System}

A principle component of extraction through SPSS on four items of a good performance appraisal system was used to estimate the number of factors which generates eigenvalues greater than one. The Kiaser-Meyer-Olkin (KMO) measure of sampling adequacy is 0.763 , indicating the sampling adequacy of greater than 0.5 for a satisfactory factor analysis is acceptable. The Bartlett's test is significant with a Chi-square value of 199.72 (p-value 0.000), with 49.773 percent of the total variance explained by this component. Table 2 shows the results of the EFA analysis on a good appraisal systems.

The One-way ANOVA test employed to determine the significance of the difference in the perceptions of the level of good performance appraisal between the four local authorities indicates that there is a significant difference between the level of perception on good performance appraisal (Table 8). The Schefee's Post Hoc multiple comparison of mean difference shows that there is a significant difference between MPP and SDC. 
Table 8: One-way ANOVA of Good Performance Appraisal of the Four Local Authorities

\begin{tabular}{lccccc}
\hline & $\begin{array}{c}\text { Sum of } \\
\text { Squares }\end{array}$ & $\begin{array}{c}\text { Degree of } \\
\text { Freedom }\end{array}$ & $\begin{array}{c}\text { Mean } \\
\text { Square }\end{array}$ & F & $\begin{array}{c}\text { Significance } \\
\text { P }\end{array}$ \\
\hline Between Groups & 4.140 & 3 & 1.380 & 6.599 & 0.000 \\
Within Groups & 49.356 & 236 & .209 & & \\
\hline Total & $\mathbf{5 3 . 4 9 6}$ & $\mathbf{2 3 9}$ & & & \\
\hline
\end{tabular}

This finding suggests that an important prerequisite for an organization to implement TQM and ISO 9000 successfully is a good appraisal system. There is a significant relationship between internal customer perceptions of good performance appraisals and the successful implementation of quality management by local authority. The result of the Spearman Rho correlation analysis confirms the research hypothesis that there is a positive relationship between the level of internal customer perceptions of the importance of good performance appraisals and the successful implementation of quality management.

A good performance appraisal, according to Safiee (2000) enhances productivity and improves the performance of an organisation. The finding of this study shows that an important prerequisite for the successful implementation of TQM and ISO 9000 is a good appraisal system. The data show that approximately 63 percent of respondents agree, and 10 percent strongly agree, that local authorities have sound appraisal systems. In addition, the data shows that 79 percent of respondents agree that the performance of the employees improved with the introduction of a good performance appraisal system in their respective organisations.

\section{Quality Assurance System}

A principle component of extraction through SPSS on four items of quality assurance system was used to estimate the number of factors which generate eigenvalues greater than one. The Kiaser-Meyer-Olkin (KMO) measure of sampling adequacy is 0.784 , indicating that the sampling adequacy of greater than 0.5 for a satisfactory factor analysis is acceptable. The Bartlett's test is significant with a Chi-square value of 98.087 (p-value 0.000 ) and the total variance of 53.772 percent for this component.

The results of a One-way ANOVA used to measure the significance of the difference between perceptions of the level of quality assurance among the four local authorities are shown in Table 9. The results indicate a significant difference in perception of the level of quality assurance $(\mathrm{F}=4.871$, $\mathrm{p}$-value 0.003$)$. The Schefee's Post Hoc multiple comparison of mean difference shows that the significant differences between MPP and BDC, and between MPP and SDC.

Table 9: One-way ANOVA of Quality Assurance System of the Four Local Authorities

\begin{tabular}{lccccc}
\hline & $\begin{array}{c}\text { Sum of } \\
\text { Squares }\end{array}$ & $\begin{array}{c}\text { Degree of } \\
\text { Freedom }\end{array}$ & $\begin{array}{c}\text { Mean } \\
\text { Square }\end{array}$ & F & $\begin{array}{c}\text { Significance } \\
\text { P }\end{array}$ \\
\hline Between Groups & 2.806 & 3 & .935 & 4.871 & 0.003 \\
Within Groups & 45.119 & 235 & .192 & & \\
\hline Total & $\mathbf{4 7 . 9 2 5}$ & $\mathbf{2 3 8}$ & & & \\
\hline
\end{tabular}


These findings support the view of Ahmad Sarji (1991a) that for the successful implementation of quality management in any organisation, there must be a quality assurance system in place. The findings also concur with Safiee (2000) who states that there is a positive relationship between quality assurance and the successful implementation of TQM in R \& DO, Limbang, Sarawak. With quality assurance put in place, it ensures that external customers should be satisfied with services provided. Hence, local authorities need to be assured that the frontline staff of the local authorities give quality service to the customers.

\section{Conclusions}

All the local authorities in this study have at least one core business certified under the MS ISO 9000 quality management systems, while other municipalities are also implementing TQM and MS ISO 9000. This study shows that all the four local authorities have been issued with the MS ISO 9000 certificate. The local authorities that have been certified with the MS ISO 9000 tend to continuously improve their management systems. PMC and DBKU have both implemented TQM and the MS ISO 9000 successfully. BDC and SDC too are also MS ISO 9000 certified. DBKU, in 2001, conducted a citizens' satisfaction survey and used the results to improve the quality system of the office and two years later implemented the IMS. However, smaller local authorities seemed to have both logistic as well as manpower constraints in implementing the system fully. Both PMC and BDC have had their application for the license certified under the MS ISO 9002: 1994, and are now in the process of migrating the certification to the MS ISO 9002: 2000. SDC, on the other hand, had its maintenance of public utilities certified under the MS ISO 9002: 1994, and SDC too, is in the process of migrating this quality system to the MS ISO 9002: 2000. DBKU is the sole local authority in this study which has all its business processes and systems certified under the MS ISO 9000, MS 14000 and OHAS, which is collectively known as an integrated management system. From the study we can safely conclude that there are several determinants in the successful implementation of quality management in the local authorities in Sarawak, Malaysia. The determinants are strongly related to factors such as top management support, strategic quality planning, customer driven, teamwork, training and recognition, good performance appraisal and quality assurance.

\section{References}

Ahmad Sarji Bin Abdul Hamid. (1991a). Perkhidmatan Awam yang Berkualiti. Kuala Lumpur: INTAN.

.(1991b). Circulars on Administrative Reforms in the Civil Service of Malaysia (1991-1996). Kuala Lumpur: Government of Malaysia.

. (1992). Kemajuan Pentadbiran Awam di Malaysia:

Koleksi Ucapan-ucapan dalam Tahun 1991. Kuala Lumpur: INTAN.

(1993a). Penerapan dan Nilai Budaya Cemerlang

dalam Perkhidmatan Awam Malaysia. Kuala Lumpur: INTAN. 
.(1993b). The Changing Civil Service. Kuala Lumpur: Pelanduk Publication.

(1993c). Upholding the Integrity of the Malaysian

Civil Service. Kuala Lumpur: Pelanduk Publications.

(1995). The Civil Service of Malaysia: Towards

Efficiency and Effectiveness. Kuala Lumpur: Percetakan Nasional Berhad.

Vision

.(1996a). Civil Service Reforms Towards Malaysia's

2020. Kuala Lumpur: Pelanduk Publications.

. (1996b).The Chief Secretary to the Government,

Malaysia. Kuala Lumpur: Pelanduk Publication.

.(1996c). "Management Values and Good

Administrative Practices for Vision 2020 in The Journal of Malaysian Institute of Management. Vol. 31, No. 1. Pp $13-18$.

.(1998). Perkhidmatan Awam Malaysia:

Meningkatkan Keutuhan Pengurusan Kerajaan Malaysia. Kuala Lumpur: Percetakan Nasional Berhad.

Deming. W. E. (1982). Quality, Productivity and Competitive Position. MIT Centre for Advance Engineering. Cambridge MA.

Deming, W. E. (1986). Out of the Crisis. Cambridge: MIT Press

Dewan Bandaraya Kuching Utara (DBKU). (2001). Laporan Tahunan. Kuching: Lee Ming Press.

Dewan Bandaraya Kuching Utara (DBKU). (2003). Procedure Manual. (Unpublished)

Dewan Bandaraya Kuching Utara (DBKU). (2004). Integrated Management System Documents. (Unpublished)

Edvardsson, Bo, Thomasson, B. and Øvretveit, J. (1994). Quality of Services: Making it Really Work. London: McGraw-Hill Book Company.

Evans, J. R., and Lindsay, W. M. (2002). TheManagement and Control of Quality. (5 Edition).Cincinnati: South-Western Thomson Learning.

Gatchalian. M. M. (1997). People Empowerment: The Key to TQM Success. The TQM Magazine. Vol. 9 (6).Pp. 429 - 433.

Gonzalez, T. F., \& Guillen, M. (2002). "Leadership ethical dimension: A requirement in TQM implementation" in the TQM Magazine. Vol. 13. No.

Ishikawa Koaru. (Translated by David. J. Lu). (1985). What is Quality Control? The 
Japanese Way. Englewood Cliffs, NJ: Prentice Hall.

Kifayah Amar \& Zuraidah Mohd. Zain. (2002). "Barriers to Implementing TQM in Indonesian Manufacturing Organizations" in The TQM Magazines. Vol. 14. No. 6. Pp. 367 - 372.

Krzysztofiak. A. (1999). The Implementation of ISO in Town Office of Kwidzyń. In: Quality Management in Public Administration. Conference papers. Dębe near Warsaw pp. 2-3.

Muhammad Rais Adbul Karim. (Ed.). (1999). Reengineering the Public Service: Leadership and Change in an Electronic Age. Subang Jaya: Pelanduk Publication.

Olian, J. D. and Rynes, S. L. (1991). 'Making Total Quality Works: Aligning organizational process, performances and stakeholders,' Human Resources Management: Vol. 30. No. 3. pp. 303-33).

Osborne, D. \& Gaebler, T. (1993). Reinventing Government: How The Entrepreneurial Spirit is Transforming the Public Sector. New York. Penguin Books USA Inc.

Saffiee Ahmad. (2000). Pengammalan Perlaksanaan Pengurusan Kualiti Menyeluruh:

Kajian Kes di Pejabat Residen dan Daerah Limbang, Sarawak. Tesis Sarjana Sains: UKM.

Taylor, B. S., and Wilson, M. (1996). TQM Implementation in New Zealand Service Organizations. The TQM Magazine. Vol. 8 (5). Pp. 56-64. 